\title{
Penerapan Pembelajaran Kooperatif Tipe Student \\ Teams Achievement Division ( STAD ) Untuk Meningkatkan Keaktifan Dan Hasil Belajar Operasi Bentuk Akar Pada Siswa Kelas X SMK 17 Agustus 1945 Surabaya
}

\author{
Ardianik $^{1 *}$, Sucipto ${ }^{2)}$ \\ ${ }^{1}$ Pendidikan Matematika, Universitas Dr. Soetomo, Surabaya, Indonesia; \\ *ardianik@unitomo.ac.id \\ ${ }_{2}^{2}$ Pendidikan Matematika, Universitas Dr. Soetomo, Surabaya, Indonesia; \\ sucipto@unitomo.ac.id
}

\begin{abstract}
Abstrak. Penelitian ini dilakukan di kelas X SMK 17 Agustus 1945 Surabaya dikarenakan peneliti melihat beberapa masalah yang dihadapi siswa dan guru dalam proses kegiatan belajar mengajar. Peneliti menemukan masalah lemahnya kemampuan siswa dalam memahami konsep operasi bentuk akar yang berdampak pada kurangnya keaktifan belajar dan hasil belajar siswa yang masih dibawah nilai KKM. Berdasarkan permasalahan tersebut, maka tujuan dari penelitian ini adalah untuk mengetahui tingkat keaktifan dan tingkat hasil belajar siswa setelah diterapkan pembelajaran kooperatif tipe STAD pada materi operasi bentuk akar. Jenis penelitian ini termasuk penelitian tindakan kelas dengan pendekatan kualitatif. Subjek dalam penelitian ini adalah siswa SMK kelas X keahlian Usaha Perjalanan Wisata (UPW) dengan jumlah siswa sebanyak 33 siswa. Metode pengumpulan data yang digunakan metode tes dan metode observasi. Metode analisis data meliputi data kualitatif dan data kuantitatif menggunakan statistik deskriptif. Hasil penelitian dari siklus I dan siklus II, menunjukkan bahwa penerapan pembelajaran kooperatif tipe STAD dapat meningkatkan keaktifan dan hasil belajar siswa. Kesimpulan dari penelitian ini bahwa penerapan model pembelajaran kooperatif tipe Student Teams Achievement Division (STAD) dapat meningkatkan keaktifan Belajar dan hasil belajar siswa pada materi operasi bentuk akar di kelas X UPW SMK 17 Agustus 1945 Surabaya.
\end{abstract}

Kata Kunci: pembelajaran kooperatif, student teams achievement division, operasi bentuk akar, keaktifan belajar

\begin{abstract}
This research was conducted in class X SMK 17 Agustus 1945 Surabaya because the researcher saw some of the problems faced by students and teachers in the process of teaching and learning activities. Researchers found the problem of students' weak abilities in understanding the concept of root form operations which resulted in a lack of active learning and student learning outcomes that were still below the KKM value. Based on these problems, the purpose of this study was to determine the level of activity and the level of student learning outcomes after the
\end{abstract}


STAD type cooperative learning was applied to the root form operation material. This type of research includes classroom action research with a qualitative approach. The subjects in this study were students of class X Vocational High School Travel Business expertise with 33 students. Data collection methods used test methods and observation methods. Data analysis methods include qualitative data and quantitative data using descriptive statistics. The results of the research from cycle I and cycle II indicate that the application of STAD type cooperative learning can increase student activity and learning outcomes. The conclusion of this research is that the application of the cooperative learning model type Student Teams Achievement Division (STAD) can increase learning activeness and student learning outcomes on the root form operation material in class X UPW SMK 17 Agustus 1945 Surabaya.

Keywords: cooperative learning, student teams achievement division, root form operations, active learning.

\section{Pendahuluan}

Penelitian ini dilakukan di SMK 17 Agustus Surabaya, berawal dari kegiatan membimbing mahasiswa praktik mengajar di kelas $X$ Jurusan Usaha Perjalanan Wisata (UPW) SMK 17 Agustus 1945, berdasarkan masukan mahasiswa yang sedang melaksanakan praktik mengajar mengatakan bahwa matematika merupakan salah satu mata pelajaran yang dianggap sulit oleh siswa, sehingga hal ini yang membuat siswa kurang aktif ketika mempelajari matematika. Pengamatan awal yang dilakukan oleh tim peneliti saat proses pembelajaran, yang hasilnya terbukti dengan kurangnya partisipasi dan keaktifan peserta didik yang bertanya, saat ditanya tidak dapat menjawab, guru menjelaskan materi secara berulang-ulang, selain itu juga kurang antusias dalam belajar yang ditunjukkan dengan adanya siswa yang tidur atau tidak memperhatikan saat proses pembelajaran. Tim peneliti juga mendapat keluhan dari beberapa siswa yang pada dasarnya merasa kesulitan khususnya mata pelajaran matematika, didukung oleh masukan guru matematika terkait rendahnya hasil belajar matematika khususnya pada materi operasi bentuk akar yang nilainya di bawah nilai KKM.

Metode pembelajaran ceramah yang selama ini digunakan di SMK 17 Agustus 1945 kurang efektif untuk meningkatkan keaktifan dan hasil belajar siswa. Hal ini dapat dilihat dari siswa yang kurang aktif selama proses pembelajaran di kelas. Siswa tidak mau bertanya apabila tidak memahami materi. Hal ini tentu memberi pengaruh besar terhadap hasil belajar mereka. Sari dan Munoto (2018) mengungkapkan bahwa penggunaan metode pembelajaran ceramah, dimana guru yang hanya fokus ada didepan kelas dapat menurunkan

Copyright (C) 2020

Buana Matematika :

Jurnal Ilmiah Matematika dan Pendidikan Matematika 
semangat belajar siswa sehingga menjadikan nilai hasil belajar siswa menurun.

Kondisi seperti di atas, perlu mendapat perhatian yang serius bagi guru matematika. Karena dalam proses belajar mengajar, pendidik atau guru memiliki peranan penting sebagai fasilitator, motivator, dan mediator. Ardillah (2016) menjelaskan bahwa dalam memperbaiki proses pembelajaran, peranan guru sangat penting. Oleh sebab itu, guru sepatutnya mampu mencari strategi yang tepat untuk dapat membelajarkan siswa melalui proses pembelajaran yang dilaksanakan, agar tujuan pembelajaran dapat tercapai efektif dan hasil belajarpun dapat ditingkatkan. Seorang guru diharapkan dapat menciptakan lingkungan belajar yang dapat meningkatkan keterlibatan siswa secara langsung dan bertanggung jawab terhadap belajar itu sendiri, karena belajar dapat diperoleh ke arah yang lebih baik, jika siswa mau belajar sebaik mungkin.

Hasil observasi tim peneliti bahwa kondisi di kelas X UPW SMK 17 Agustus 1945 pada saat kegiatan belajar mengajar, kenyataannya guru matematika masih menerapkan pembelajaran ceramah dalam menjelaskan konsep operasi bentuk akar, sehingga siswa menjadi pasif, kurangnya partisipasi, yang menyebabkan lemahnya kemampuan siswa dalam memahami konsep operasi bentuk akar dan berdampak pada kurangnya keaktifan belajar dan hasil belajar siswa yang masih dibawah nilai KKM.

Berdasarkan urgensi tersebut maka tim peneliti perlu memilih model pembelajaran yang disesuaikan dengan karakteristik materi, siswa dan lingkungan belajar, yang dapat meningkatkan keaktifan belajar dan membangun semangat belajar siswa agar tidak monoton. Model Pembelajaran yang sesuai dengan kondisi siswa kelas X UPW SMK 17 Agustus 1945 yaitu model pembelajaran Kooperatif Tipe Student Teams Achievement Division (STAD), didukung oleh penelitian (Arif, 2016) tentang “Pengaruh penerapan model pembelajaran kooperatif tipe STAD terhadap hasil belajar siswa", dimana hasilnya menunjukkan bahwa ada pengaruh penerapan model pembelajaran kooperatif tipe STAD terhadap hasil belajar siswa. Menurut Desriyana (2016) bahwa model pembelajaran kooperatif tipe STAD merupakan salah satu model pembelajaran yang menekankan adanya aktifitas dan interaksi diantara siswa untuk saling memotivasi dan saling membantu dalam menguasai materi pelajaran guna mencapai prestasi yang maksimal. Keunggulan dari model ini adalah pembelajarannya menekankan pada siswa

Copyright (C) 2020

Buana Matematika :

Jurnal Ilmiah Matematika dan Pendidikan Matematika 
untuk bekerja sama dalam mencapai tujuan dengan menjunjung tinggi norma-norma kelompok, aktif membantu dan memotivasi semangat untuk berhasil bersama, aktif berperan sebagai tutor sebaya untuk lebih meningkatkan keberhasilan kelompok, serta interaksi siswa seiring dengan peningkatan kemampuan mereka dalam berpendapat. Perbedaan penelitian sebelumnya, sebagian besar menitikberatkan pada pengaruh pembelajaran kooperatif tipe STAD terhadap hasil belajar siswa saja, tetapi pada penelitian ini tidak hanya berpengaruh pada hasil belajar, juga berpengaruh pada keaktifan belajar siswa terutama dalam aspek: bertanya kepada guru, menjawab pertanyaan guru, menuliskan jawaban LKS, diskusi kelompok, bekerja sama dengan kelompok, mengemukakan pendapat, mendengarkan penjelasan guru, percaya diri dalam kegiatan belajar mengajar.

Penelitian yang dilakukan oleh Eminingsih (2013) menyatakan bahwa penerapan model pembelajaran kooperatif tipe STAD dapat meningkatkan hasil belajar dan aktifitas siswa pada mata pelajaran matematika. Di dukung penelitian yang dilakukan oleh Kalim dan Siti Andriani (2013) menyatakan model pembelajaran kooperatif tipe STAD memiliki dampak positif dalam meningkatkan prestasi belajar siswa yang ditandai dengan peningkatan ketuntasan belajar setiap siklus serta dapat meningkatkan aktifitas belajar siswa. Menurut Rachmawati, dkk. (2018) model pembelajaran kooperatif tipe STAD merupakan model pembelajaran kooperatif yang menekankan pada pembagian siswa dalam kelompok-kelompok untuk memahami suatu materi pelajaran dan setiap siswa bertanggung jawab atas penguasaan materi dari setiap anggota kelompoknya. Siswa dituntut untuk saling membantu dalam memahami materi. Siswa yang belum paham akan diajari oleh siswa yang sudah paham dalam satu kelompoknya.

Keaktifan belajar merupakan salah satu hal yang paling penting dalam proses belajar mengajar. Dimana keaktifan menjadi salah satu tolak ukur pengajar untuk mengetahui apakah siswa fokus dan mengerti apa yang telah dijelaskan oleh pengajar. Dalam kondisi ini siswa tidak hanya sekedar mengamati dan mendengarkan saja, tetapi secara tidak langsung terlibat dalam proses belajar mengajar. Menurut Sudjana (2016) keaktifan siswa dalam proses belajar mengajar sangat penting, dengan memperhatikan indikator keaktifan siswa sebagai berikut: a) ikut terlibat dalam pelaksanaan kegiatan belajar; b) ikut dalam pemecahan masalah atau mengemukakan pendapat; c) bertanya jika ada soal yang belum dipahami ; d) berusaha mempelajari materi pelajaran, mencari, dan mencatat berbagai informasi yang diperlukan untuk pemecahan Copyright $\odot 2020$

\section{Buana Matematika :}

Jurnal Ilmiah Matematika dan Pendidikan Matematika 
masalah; e) ikut serta dalam diskusi secara berkelompok; f) mempelajari secara mandiri soal yang telah diberikan; g) ikut serta dalam menyelesaikan tugas belajar; h) menyelesaikan tugas belajar dengan menerapkan materi yang telah diperoleh sebelumnya.

Hasil belajar merupakan suatu istilah yang digunakan untuk merujuk sesuatu yang dicapai oleh seseorang setelah melakukan suatu usaha berupa proses belajar dalam waktu tertentu. Winkel (1996) juga mendefinisikan hasil belajar sebagai semua perubahan di bidang kognitif, sensorik-motorik, dan dinamikafektif yang mengakibatkan manusia berubah dalam sikap dan tingkah lakunya. Hasil belajar ini merupakan suatu kemampuan internal (capability) yang telah menjadi milik pribadi seseorang dan memungkinkan orang itu melakukan sesuatu atau memberikan prestasi tertentu (performance). Menurut Rusman (2016) hasil belajar adalah sejumlah pengalaman yang diperoleh siswa yang mencakup ranah kognitif, afektif, dan psikomotorik. Hasil belajar tampak sebagai terjadinya perubahan tingkah laku pada diri siswa, yang dapat diamati dan diukur dalam bentuk perubahan sikap dan keterampilan.

Berdasarkan uraian di atas, maka tujuan dalam penelitian ini adalah:1) Untuk mengetahui tingkat keaktifan siswa setelah diterapkan model Pembelajaran Kooperatif tipe Student Teams Achievement Division (STAD) pada materi operasi Bentuk Akar; 2) Untuk mengetahui tingkat hasil belajar siswa setelah diterapkan model pembelajaran kooperatif tipe Student Teams Achievement Division ( STAD ) pada materi operasi bentuk akar.

\section{Metode Penelitian}

Jenis penelitian ini menggunakan Penelitian Tindakan Kelas (Classroom Action Research) dengan pendekatan kualitatif, subjek penelitian ini adalah siswa SMK kelas X keahlian Usaha Perjalanan Wisata (UPW) dengan jumlah siswa sebanyak 33 siswa yang terdiri dari 6 siswa laki-laki dan 27 siswa perempuan dengan kemampuan yang heterogen (berbeda). Jenis data yaitu data kualitatif diperoleh melalui pengamatan langsung terhadap keaktifan belajar siswa, sedangkan data kuantitatif diperoleh melalui hasil tes. Instrumen dalam penelitian berupa soal tes dan lembar observasi, soal tes digunakan untuk mengukur hasil belajar siswa dari ranah kognitif setelah dilakukan tindakan pembelajaran menggunakan model pembelajaran kooperatif tipe STAD. Soal tes berupa soal uraian yang berjumlah 5 butir soal yang sudah valid karena diadaptasi dari soal ujian nasional dan tetap divalidasi oleh dua validator yang berkompeten. Lembar observasi untuk mengukur tingkat aktifitas siswa

Copyright (C) 2020

Buana Matematika :

Jurnal Ilmiah Matematika dan Pendidikan Matematika 
berdasarkan akumulasi nilai yang dikategorikan sesuai tingkatan aktifitas. Metode pengumpulan data dengan metode tes dan observasi. Rencana Pelaksanaan tindakan digambarkan diagram di bawah ini :

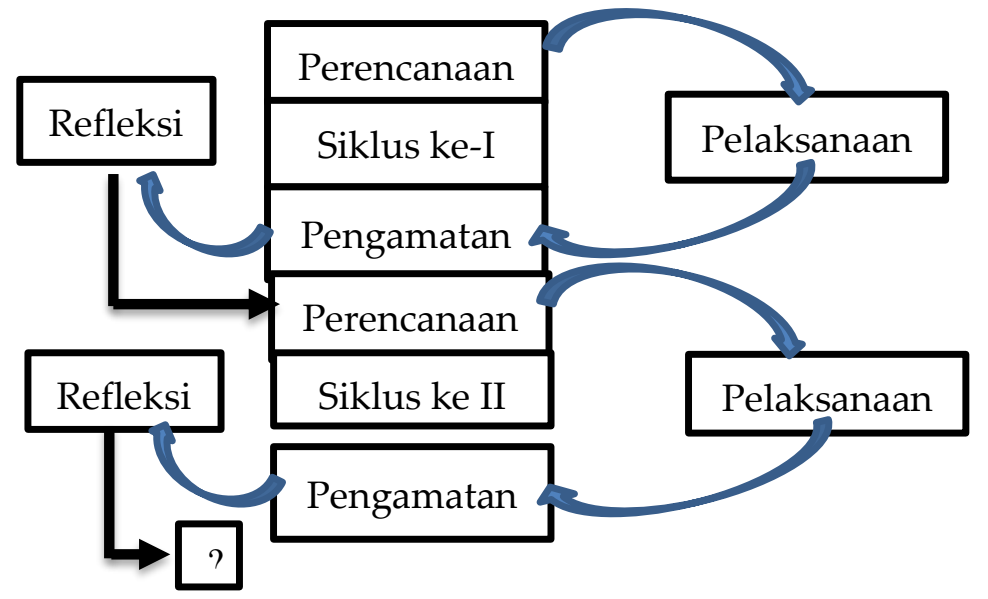

Gambar 1. Siklus Penelitian Tindakan (Arikunto, 2015)

Metode analisis data ada dua yaitu: a) Metode analisa data kualitatif yaitu data tentang keaktifan siswa dengan menggunakan skala penilaian angka $(4,3,2,1)$, angka 4 = sangat baik, angka $3=$ baik, angka 2 = kurang, angka 1 = sangat kurang. Indikator keaktifan belajar siswa dapat dilihat pada Tabel 1 berikut ini:

Tabel 1. Indikator Keaktifan Belajar Siswa

\begin{tabular}{|c|c|c|}
\hline No. & Aspek & Indikator Keaktifan \\
\hline \multirow[t]{3}{*}{1} & \multirow{3}{*}{$\begin{array}{l}\text { Bertanya } \\
\text { kepada } \\
\text { guru }\end{array}$} & $\begin{array}{l}\text { Bertanya dengan aktif kepada guru tentang materi yang } \\
\text { dipelajari }\end{array}$ \\
\hline & & Kurang aktif dalam bertanya tentang materi yang dipelajari \\
\hline & & $\begin{array}{l}\text { Tidak mengajukan pertanyaan atau melakukan aktivitas di luar } \\
\text { kegiatan }\end{array}$ \\
\hline \multirow[t]{3}{*}{2} & \multirow{3}{*}{$\begin{array}{l}\text { Menjawab } \\
\text { pertanyaa } \\
\text { n guru }\end{array}$} & $\begin{array}{l}\text { Mampu memberikan jawaban guru dengan tepat sesuai } \\
\text { pertanyaan }\end{array}$ \\
\hline & & Mampu menjawab pertanyaan guru namun belum tepat \\
\hline & & Tidak menjawab pertanyaan guru \\
\hline \multirow[t]{3}{*}{3} & \multirow{3}{*}{$\begin{array}{l}\text { Menuliska } \\
\text { n jawaban } \\
\text { LKS }\end{array}$} & Menuliskan jawaban LKS secara mandiri dan tepat \\
\hline & & Menuliskan jawaban LKS dengan melihat jawaban teman \\
\hline & & Tidak menuliskan jawaban LKS \\
\hline \multirow[t]{3}{*}{4} & \multirow{3}{*}{$\begin{array}{l}\text { Diskusi } \\
\text { Kelompok }\end{array}$} & Aktif berdiskusi dalam kelompok \\
\hline & & Kurang aktif dalam diskusi kelompok \\
\hline & & $\begin{array}{l}\text { Tidak melakukan diskusi atau melakukan aktivitas di luar yang } \\
\text { diamati }\end{array}$ \\
\hline
\end{tabular}

Copyright (c) 2020

Buana Matematika :

Jurnal Ilmiah Matematika dan Pendidikan Matematika 


\begin{tabular}{|c|c|c|}
\hline No. & Aspek & Indikator Keaktifan \\
\hline \multirow[t]{3}{*}{5} & \multirow{3}{*}{$\begin{array}{l}\text { Bekerjasam } \\
\text { a dengan } \\
\text { kelompok }\end{array}$} & Mampu bekerja sama dengan baik dalam kegiatan kelompok \\
\hline & & Mampu bekerja sama cukup baik dalam kegiatan kelompok \\
\hline & & Tidak mampu bekerja sama dalam kegiatan kelompok \\
\hline \multirow[t]{3}{*}{6} & \multirow{3}{*}{$\begin{array}{l}\text { Mengemu- } \\
\text { kakan Pen- } \\
\text { dapat }\end{array}$} & Mampu memberikan pendapat dengan baik dan benar \\
\hline & & Hanya melihat teman lain dalam mengemukakan pendapat \\
\hline & & $\begin{array}{l}\text { Tidak mengemukakan pendapat atau melakukan aktivitas di } \\
\text { luar kegiatan }\end{array}$ \\
\hline \multirow[t]{3}{*}{7} & \multirow{3}{*}{$\begin{array}{l}\text { Mendenga } \\
\text { rkan penje- } \\
\text { lasan/Infor } \\
\text { masi guru }\end{array}$} & Mendengarkan dengan tenang penjelasan/informasi guru \\
\hline & & $\begin{array}{l}\text { Mendengarkan namun kurang tenang penjelasan/informasi } \\
\text { guru }\end{array}$ \\
\hline & & $\begin{array}{l}\text { Tidak mendengarkan penjelasan/informasi guru atau } \\
\text { melakukan aktivitas diluar kegiatan yang diamati }\end{array}$ \\
\hline \multirow[t]{3}{*}{8} & \multirow{3}{*}{$\begin{array}{l}\text { Percaya } \\
\text { diri dalam } \\
\text { kegiatan } \\
\text { belajar } \\
\text { mengajar }\end{array}$} & Percaya diri tinggi dalam mengikuti kegiatan pembelajaran \\
\hline & & Percaya diri cukup dalam mengikuti kegiatan pembelajaran \\
\hline & & Tidak percaya diri dalam mengikuti kegiatan pembelajaran \\
\hline
\end{tabular}

Untuk menghitung persentase keaktifan belajar siswa, sebagai berikut:

- $\quad$ Persentase keaktifan siswa (Vellayati, 2017)

Persentase Keaktifan siswa

$$
=\frac{\text { skor mentah yang di peroleh siswa }}{\text { Skor maksimal keaktifan }} \times 100 \%
$$

- $\quad$ Persentase rata-rata Keaktifan siswa (Nurkhikmah, 2013)

$$
\begin{aligned}
& \text { Rata }- \text { Rata Keaktifan siswa } \\
& \qquad=\frac{\text { skor keseluruhan yang di peroleh }}{\text { Jumlah siswa } \times \text { skor maksimum }} \times 100 \%
\end{aligned}
$$

Selanjutnya dianalisis untuk mengetahui kriteria pencapaian keberhasilan aktifitas siswa dengan menggunakan kategori sebagai berikut.

Tabel 2. Skala Penilaian

\begin{tabular}{cccccc}
\hline No & Nilai & Persentase & Predikat & Skala & Kategori \\
\hline 1. & $75-100$ & $75 \%-100 \%$ & A & 4 & Sangat Baik \\
\hline 2. & $74,99-50$ & $74,99 \%-50 \%$ & B & 3 & Baik \\
\hline 3. & $49,99-25$ & $49,99 \%-25 \%$ & C & 2 & Kurang \\
\hline 4. & $0-24,99$ & $24,99 \%-0 \%$ & D & 1 & Sangat Kurang \\
\hline
\end{tabular}

Sumber : Nurkhikmah, 2013

b) Metode analisis data kuantitatif berupa hasil belajar yang dilakukan setiap akhir siklus tindakan, dengan memberikan tes yang menggunakan lembar

Copyright (C) 2020

Buana Matematika :

Jurnal Ilmiah Matematika dan Pendidikan Matematika 
kerja siswa (LKS). Bentuk tes subyektifitas, dan banyaknya soal 5 butir soal. Rumus menghitung ketuntasan belajar (Yudianto, 2014):

1. Ketuntasan belajar individu, data yang diperoleh dari hasil belajar peserta didik dapat ditentukan ketuntasan belajar individu, dengan kriteria berikut: Tuntas, jika nilai $\geq 75$ dan Tidak tuntas, jika nilai $<75$

2. Ketuntasan belajar secara klasikal,dapat dihitung dengan rumus:

$$
\text { Ketuntasan Klasikal }=\frac{\text { jumlah siswa yang tuntas }}{\text { jumlah seluruh siswa }} \times 100 \%
$$

Indikator keberhasilan dalam tindakan ini adalah peningkatan keaktifan dan hasil belajar siswa. Berdasarkan pertimbangan kondisi pembelajaran di SMK 17 Agustus 1945 kelas X keahlian Usaha Perjalanan Wisata (UPW) pada materi operasi bentuk akar, maka indikator keberhasilan menurut (Setyadi dan Supartini, 2014) ditentukan:

1. Minimal $70 \%$ dari jumlah siswa yang ada terlibat aktif dalam proses pembelajaran dengan skor minimal 50 (kategori baik) dari seluruh aspek penilaian.

2. Minimal jumlah siswa yang mendapatkan nilai $75(\mathrm{KKM})$ sebesar $75 \%$ dari jumlah siswa yang ada dengan persentase ketuntasan klasikal sebesar 75 $\%$.

\section{Hasil dan Pembahasan}

\section{A. Deskripsi Data Pra Siklus}

Sebelum pelaksanaan penelitian tindakan kelas menggunakan model pembelajaran kooperatif tipe STAD, terlebih dahulu dilakukan pre-test dengan tujuan untuk mengetahui hasil belajar awal siswa pada pokok bahasan operasi bentuk akar, dan terkait dengan permasalahan dilapangan bahwa hasil belajar siswa pada pokok bahasan operasi bentuk akar masih di bawah nilai KKM. Pelaksanaan prasiklus dilaksanakan satu kali pertemuan. Hasil pre-tes siswa kelas X UPW SMK 17 Agustus 1945, menunjukkan hasil belajar yang masih rendah,dibawah nilai KKM pelajaran matematika yaitu 75 . Hasil pre test dari 33 siswa menunjukkan sebanyak 8 atau 24,24\% siswa mendapatkan nilai $\geq$ nilai KKM. Sedangkan sebanyak 25 atau $75,76 \%$ siswa memperoleh nilai < nilai KKM, dan nilai rata-rata kelas diperoleh 37,90. Berdasarkan data pre-test di atas, maka peneliti berkeinginan untuk meningkatkan hasil belajar dan keaktifan siswa melalui model pembelajaran kooperatif tipe STAD.

\section{B. Siklus I}

\section{Analisis Data Kualitatif}

Copyright $@ 2020$

\section{Buana Matematika :}

Jurnal Ilmiah Matematika dan Pendidikan Matematika 
Analisis data kualitatif pada penelitian ini berupa data keaktifan siswa yang diperoleh melalui lembar pengamatan yang didapatkan selama proses tindakan dilaksanakan. Berikut data hasil analisis keaktifan siswa selama tindakan siklus I.

Tabel 3. Data Hasil Analisis Keaktifan Siswa Siklus I

\begin{tabular}{|c|c|c|c|c|}
\hline No & Nama Siswa & $\begin{array}{c}\text { Skor Perolehan } \\
\text { Siswa }\end{array}$ & $\begin{array}{c}\text { Persentase } \\
\text { keaktifan Siswa }\end{array}$ & Kategori \\
\hline 1. & Shanty Dwi Wahyuni & 70 & $72,92 \%$ & Baik \\
\hline 2. & Eri Isdayah & 70 & $72,92 \%$ & Baik \\
\hline 3. & Fany Maharani & 66 & $68,75 \%$ & Baik \\
\hline 4. & Zakyah Hozalita & 67 & $69,79 \%$ & Baik \\
\hline 5. & Salma Shafira & 60 & $62,50 \%$ & Baik \\
\hline 6. & Ariena Agustin & 61 & $63,54 \%$ & Baik \\
\hline 7. & Stephany Tri Amanda & 68 & $70,83 \%$ & Baik \\
\hline 8. & Shifana Ajeng Pangeswari & 66 & $68,75 \%$ & Baik \\
\hline 9. & Sendy Kurnia Oktavia & 73 & $76,04 \%$ & Baik \\
\hline 10. & Fahar Satyama & 70 & $72,92 \%$ & Baik \\
\hline 11. & Warda Dwi Oktavia & 66 & $68,75 \%$ & Baik \\
\hline 12. & Muhammad Rafli & 49 & $51,04 \%$ & Baik \\
\hline 13. & Shapira Yosi & 78 & $81,25 \%$ & Baik \\
\hline & Ratu Kayla & - & - & - \\
\hline 15. & Taufik Hidayat & 57 & $59,38 \%$ & Baik \\
\hline 16. & Bagas Febrian R. & 63 & $65,62 \%$ & Baik \\
\hline 17. & Nur Fitriany & 73 & $76,04 \%$ & Sangat baik \\
\hline 18. & Putri Carla & 65 & $67,70 \%$ & Baik \\
\hline & Laila Rachmadani & - & - & - \\
\hline 20. & Humbela Putri Tael & 78 & $81,25 \%$ & Sangat baik \\
\hline & Adelia Nimalasari & 67 & $69,79 \%$ & Baik \\
\hline & Adinda Trinita & - & - & - \\
\hline 23. & Bagus Febrian Shidiq & 54 & $56,25 \%$ & Baik \\
\hline & Ryansyah Rahmadani & 69 & $71,87 \%$ & Baik \\
\hline & Dewi Fatmawati & 63 & $65,62 \%$ & Baik \\
\hline & Melia Bimbi Ferdhianty & 59 & $61,46 \%$ & Baik \\
\hline & Nur Kholifah & - & - & - \\
\hline & Priskila Tivena & 70 & $72,92 \%$ & Baik \\
\hline & Fanny Octania & 60 & $62,50 \%$ & Baik \\
\hline & Yulistia Blandina & 68 & $70,83 \%$ & Baik \\
\hline 31. & Muhammad Ryan & 56 & $58,33 \%$ & Baik \\
\hline & Fania Tifara & 61 & $63,54 \%$ & Baik \\
\hline 33. & Shierly Alvany & 56 & $58,33 \%$ & Baik \\
\hline & Jumlah Skor Perolehan & & 1883 & \\
\hline Rat & ta-rata skor Perolehan Siswa & & 64,93 & \\
\hline Rat & $\begin{array}{c}\text { ta-rata Persentase Keaktifan } \\
\text { Siswa }\end{array}$ & & $67,64 \%$ & Baik \\
\hline
\end{tabular}

Copyright (C) 2020

Buana Matematika :

Jurnal Ilmiah Matematika dan Pendidikan Matematika 
Tabel 3 di atas, menunjukkan hasil analisis data keaktifan siswa kelas X UPW SMK 17 Agustus 1945 selama proses pembelajaran siklus I dengan menggunakan model pembelajaran kooperatif tipe STAD. Dari data di atas, sebanyak 2 atau 6,06\% siswa yang mendapat kategori sangat baik, dan 27 atau $81,82 \%$ siswa yang mendapat kategori baik, dan 4 atau 12,12\% siswa yang tidak hadir saat pembelajaran siklus I dilaksanakan. Berdasarkan hasil analisis data keaktifan yang diperoleh pada siklus I, dengan rata-rata persentase keaktifan siswa sebesar $67,64 \%$ yang masih dibawah kriteria keberhasilan sebesar $70 \%$ maka perlu adanya pengamatan keaktifan pada siklus II untuk mengetahui apakah ada peningkatan rata-rata keaktifan belajar siswa saat menggunakan model kooperatif tipe STAD atau tidak ada.

\section{Analisis Data Kuantitatif}

a) Perencanaan ( Plan)

Tahap perencanaan meliputi: 1) Merancang pembelajaran dengan model pembelajaran kooperatif tipe STAD; 2) Menyusun Rencana Pelaksanaan Pembelajaran (RPP) Operasi bentuk akar; 3) Merancang lembar tes untuk digunakan pada akhir siklus.

b) Pelaksanaan Tindakan ( Act)

Tahap tindakan pada siklus I yaitu melakukan pembelajaran dengan model pembelajaran kooperatif tipe STAD. yang dilakukan selama 4 x 45 menit. Sebelum kegiatan dimulai, dilakukan presensi siswa terlebih dahulu untuk mengetahui jumlah siswa yang hadir dan yang tidak hadir. Siswa yang hadir pada tindakan pertama sebanyak 29 siswa. Tahap tindakan dilakukan sesuai dengan skenario yang telah dibuat dan perangkat yang telah disiapkan oleh tim peneliti.

c) Pengamatan (Observe)

Berdasarkan hasil tes pada pelaksanaan akhir siklus I yang bertujuan untuk mengetahui hasil belajar siswa dengan menerapkan model pembelajaran kooperatif tipe STAD di kelas X UPW SMK 17 Agustus 1945 didapatkan hasil sebagai berikut.

Tabel 4. Analisis Data Hasil Tes Siklus I

\begin{tabular}{clcc}
\hline No & Nama Siswa & Nilai Siklus I & Keterangan \\
\hline 1. & Shanty Dwi Wahyuni & 95 & Tuntas \\
\hline 2. & Eri Isdayah & 70 & Tidak tuntas \\
\hline 3. & Fany Maharani & 35 & Tidak tuntas \\
\hline 4. & Zakyah Hozalita & 75 & Tuntas \\
\hline 5. & Salma Shafira & 80 & Tuntas \\
\hline 6. & Ariena Agustin & 40 & Tidak tuntas \\
\hline
\end{tabular}

Copyright $@ 2020$

Buana Matematika :

Jurnal Ilmiah Matematika dan Pendidikan Matematika 


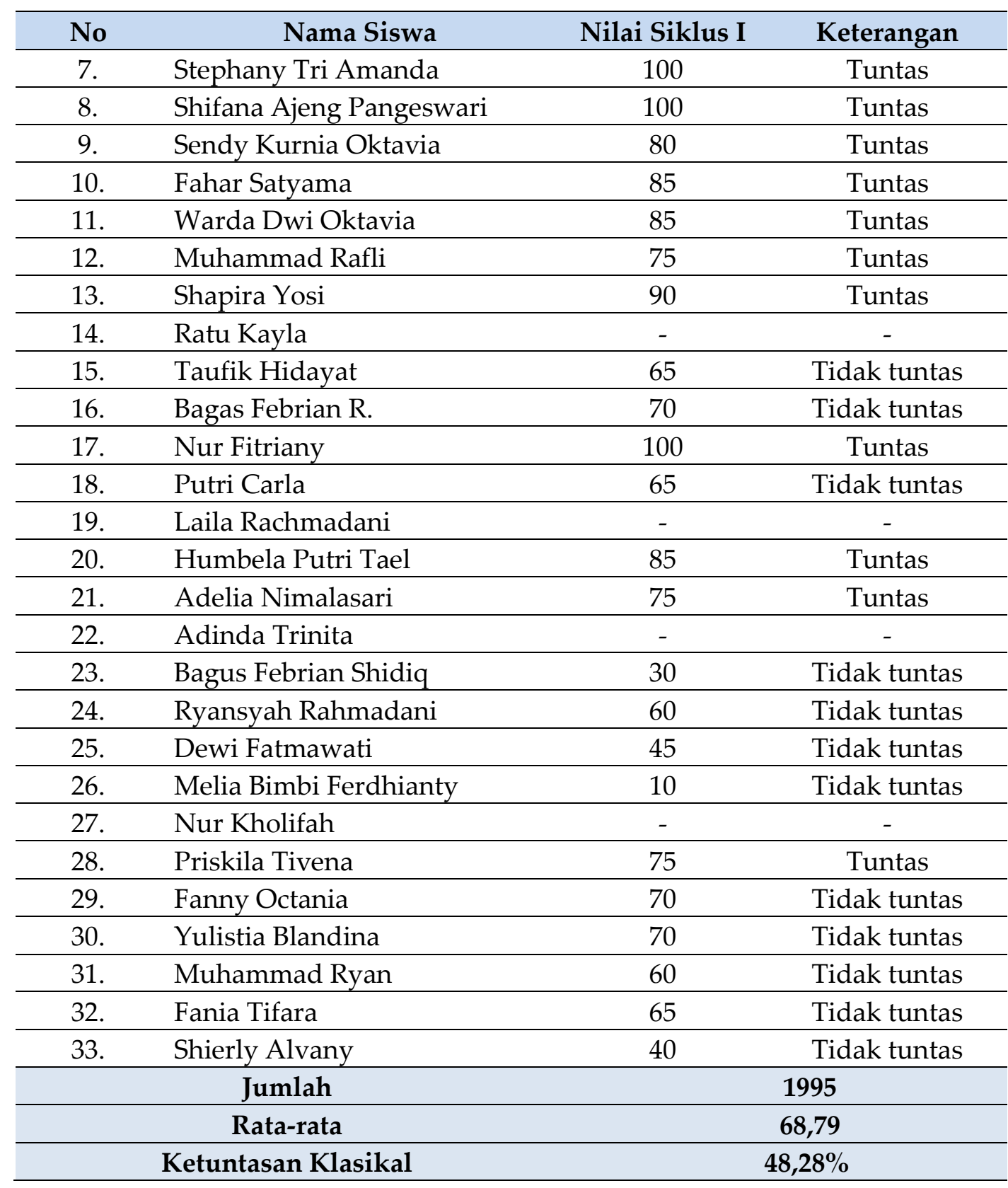

Tabel 4 di atas menunjukkan analisis hasil tes secara individu maupun secara klasikal pada siklus I dengan menggunakan model pembelajaran kooperatif tipe STAD. Hasilnya menunjukkan bahwa dari 29 siswa yang mengikuti tes, hanya 14 atau 48,28\% siswa yang mendapat nilai $\geq K K M$, sedangkan 15 atau $51,72 \%$ siswa mendapat nilai < nilai KKM.

d) Refleksi (Reflection)

Pelaksanaan pembelajaran pada siklus I telah sesuai dengan rencana semula. Walaupun alokasi waktunya tepat, secara umum penerapan model pembelajaran kooperatif tipe STAD pada siklus I belum mencapai hasil

Copyright (C) 2020

\section{Buana Matematika :}

Jurnal Ilmiah Matematika dan Pendidikan Matematika 
yang optimal. Beberapa kelemahan yang ditemukan saat proses pembelajaran siklus I adalah sebagai berikut: 1)Masih banyak siswa yang tidak bertanya kepada temannya ketika mengalami kesulitan dalam menyelesaikan soal diskusi; 2)Kurangnya kerjasama antar siswa, sehingga ada beberapa siswa yang belum memahami pembahasan dari soal;3)Hasil tes belum mencapai indikator keberhasilan yang ditetapkan yaitu 75\%. Upaya perbaikan yang akan dilaksanakan dalam siklus II agar pembelajaran berlangsung lebih baik adalah sebagai berikut: 1)Memberi motivasi kepada siswa agar berperan aktif dalam setiap diskusi yang dilakukan selama pembelajaran; 2)Memberi motivasi kepada siswa tentang pentingnya kerjasama dan tolong menolong dalam suatu kelompok maupun dalam hubungan individu dengan individu; 3)Peneliti tetap berkeliling saat proses diskusi berlangsung, untuk mengetahui sejauh mana siswa yang memiliki kemampuan yang tinggi mengajari temannya yang memiliki kemampuan kurang.

\section{Siklus II}

\section{Analisis Data Kualitatif}

Analisis data kualitatif pada tindakan siklus II berupa data keaktifan siswa yang diperoleh melalui lembar pengamatan selama proses pelaksanaan tindakan siklusi II. Pengamatan dilakukan oleh tim peneliti dengan bantuan guru. Berikut data hasil analisis keaktifan siswa selama tindakan siklus II.

Tabel 5. Data Hasil Analisis Keaktifan Siswa Siklus II

\begin{tabular}{clccc}
\hline No & \multicolumn{1}{c}{ Nama Siswa } & $\begin{array}{c}\text { Skor perolehan } \\
\text { siswa }\end{array}$ & $\begin{array}{c}\text { Persentase } \\
\text { keaktifan siswa }\end{array}$ & Kategori \\
\hline 1. & Shanty Dwi Wahyuni & 86 & $89,58 \%$ & Sangat baik \\
\hline 2. & Eri Isdayah & 80 & $83,34 \%$ & Sangat baik \\
\hline 3. & Fany Maharani & 60 & $62,5 \%$ & Baik \\
\hline 4. & Zakyah Hozalita & 64 & $66,67 \%$ & Baik \\
\hline 5. & Salma Shafira & 64 & $66,67 \%$ & Baik \\
\hline 6. & Ariena Agustin & 59 & $61,46 \%$ & Baik \\
\hline 7. & Stephany Tri Amanda & 87 & $90,63 \%$ & Sangat baik \\
\hline 8. & Shifana & 80 & $83,34 \%$ & Sangat baik \\
& Pangeswari & & & \\
\hline 9. & Sendy Kurnia Oktavia & 57 & $59,38 \%$ & Baik \\
\hline 10. & Fahar Satyama & 69 & $71,88 \%$ & Baik \\
\hline 11. & Warda Dwi Oktavia & 70 & $72,92 \%$ & Baik \\
\hline 12. & Muhammad Rafli & 72 & $75 \%$ & Sangat baik \\
\hline 13. & Shapira Yosi & 86 & $89,58 \%$ & Sangat baik \\
\hline 14. & Ratu Kayla & 86 & $89,58 \%$ & Sangat baik \\
\hline Copyratgh
\end{tabular}

Copyright $@ 2020$

Buana Matematika :

Jurnal Ilmiah Matematika dan Pendidikan Matematika 


\begin{tabular}{|c|c|c|c|c|}
\hline No & Nama Siswa & $\begin{array}{c}\text { Skor perolehan } \\
\text { siswa }\end{array}$ & $\begin{array}{c}\text { Persentase } \\
\text { keaktifan siswa }\end{array}$ & Kategori \\
\hline 15. & Taufik Hidayat & 67 & $69,69 \%$ & Baik \\
\hline 16. & Bagas Febrian R. & 63 & $65,63 \%$ & Baik \\
\hline 17. & Nur Fitriany & 85 & $88,54 \%$ & Sangat baik \\
\hline 18. & Putri Carla & 75 & $78,12 \%$ & Sangat baik \\
\hline 19. & Laila Rachmadani & 67 & $69,69 \%$ & Baik \\
\hline 20. & Humbela Putri Tael & 89 & $92,70 \%$ & Sangat baik \\
\hline 21. & Adelia Nimalasari & 84 & $87,5 \%$ & Sangat baik \\
\hline 22. & Adinda Trinita & 74 & $77,08 \%$ & Sangat baik \\
\hline 23. & Bagus Febrian Shidiq & 64 & $66,67 \%$ & Baik \\
\hline 24. & Ryansyah Rahmadani & 69 & $71,88 \%$ & Baik \\
\hline 25. & Dewi Fatmawati & 77 & $80,20 \%$ & Sangat baik \\
\hline 26. & Melia Bimbi Ferdhianty & 64 & $66,67 \%$ & Baik \\
\hline 27. & Nur Kholifah & 84 & $87,50 \%$ & Sangat baik \\
\hline 28. & Priskila Tivena & 86 & $89,58 \%$ & Sangat baik \\
\hline 29. & Fanny Octania & 78 & $81,25 \%$ & Sangat baik \\
\hline 30. & Yulistia Blandina & 70 & $72,92 \%$ & Baik \\
\hline 31. & Muhammad Ryan & 60 & $62,50 \%$ & Baik \\
\hline 32. & Fania Tifara & 60 & $62,50 \%$ & Baik \\
\hline & Shierly Alvany & 64 & $66,67 \%$ & Baik \\
\hline \multicolumn{2}{|c|}{ Jumlah Skor Perolehan } & \multicolumn{3}{|c|}{2400} \\
\hline \multicolumn{2}{|c|}{$\begin{array}{c}\text { Rata-rata Skor Perolehan } \\
\text { Siswa } \\
\end{array}$} & \multicolumn{3}{|c|}{72,73} \\
\hline \multicolumn{2}{|c|}{$\begin{array}{c}\text { Rata-rata persentase keaktifan } \\
\text { siswa }\end{array}$} & \multicolumn{2}{|r|}{$75,76 \%$} & $\begin{array}{c}\text { Sangat } \\
\text { Baik }\end{array}$ \\
\hline
\end{tabular}

Tabel 5 menunjukkan hasil analisis data keaktifan siswa kelas X UPW SMK 17 Agustus 1945 yang diperoleh melalui lembar pengamatan selama pembelajaran siklus II dengan menggunakan model pembelajaran kooperatif tipe STAD pada materi operasi bentuk akar. Hasilnya menunjukkan bahwa sebanyak 16 atau 48,48\% siswa mendapat kategori sangat baik dan sebanyak 17 atau 51,52\% siswa mendapat kategori baik. Sedangkan rata-rata persentase keaktifan siswa secara keseluruhan sebesar 75,76\%, dengan kategori sangat baik. Berdasarkan hasil diatas menunjukkan bahwa dengan menggunakan model pembelajaran kooperatif tipe STAD pada materi operasi bentuk akar ternyata siswa sangat aktif dalam kegiatan belajar mengajar.

\section{Analisis Data Kuantitatif}


Analisis data kuantitatif penelitian ini adalah data hasil tes digunakan untuk mengukur hasil belajar siswa dengan menerapkan model pembelajaran kooperatif tipe STAD.

a) Perencanaan ( Plan)

Tahap perencanaan meliputi: 1) Merancang pembelajaran dengan model pembelajaran kooperatif tipe STAD; 2) Menyusun Rencana Pelaksanan Pembelajaran (RPP) Operasi bentuk akar; 3) Merancang lembar tes untuk digunakan pada akhir siklus.

b) Pelaksanaan Tindakan ( Act)

Pelaksanaan Tindakan Kelas (PTK) pada siklus II, tahap tindakan yaitu melakukan pembelajaran dengan model pembelajaran kooperatif tipe STAD. Pelaksanaan Tindakan Kelas siklus II dilakukan selama 4 x 45 menit. Sebelum kegiatan dimulai, dilakukan presensi siswa terlebih dahulu untuk mengetahui jumlah siswa yang hadir dan yang tidak hadir. Siswa yang hadir pada Siklus II sebanyak 33 siswa. Tahap tindakan dilakukan sesuai skenario yang dibuat dan perangkat yang disiapkan.

c) Pengamatan (Observe)

Berdasarkan hasil tes pada pelaksanaan akhir siklus II yang bertujuan untuk mengetahui hasil belajar siswa dengan menerapkan model pembelajaran kooperatif tipe STAD , didapatkan hasil sebagai berikut:

Tabel 6. Analisis Data Hasil Tes Siklus II

\begin{tabular}{clcc}
\hline No & \multicolumn{1}{c}{ Nama Siswa } & Nilai Siklus II & Keterangan \\
\hline 1. & Shanty Dwi Wahyuni & 100 & Tuntas \\
\hline 2. & Eri Isdayah & 100 & Tuntas \\
\hline 3. & Fany Maharani & 75 & Tuntas \\
\hline 4. & Zakyah Hozalita & 100 & Tuntas \\
\hline 5. & Salma Shafira & 75 & Tuntas \\
\hline 6. & Ariena Agustin & 70 & Tidak tuntas \\
\hline 7. & Stephany Tri Amanda & 100 & Tuntas \\
\hline 8. & Shifana Ajeng Pangeswari & 100 & Tuntas \\
\hline 9. & Sendy Kurnia Oktavia & 95 & Tuntas \\
\hline 10. & Fahar Satyama & 95 & Tuntas \\
\hline 11. & Warda Dwi Oktavia & 95 & Tuntas \\
\hline 12. & Muhammad Rafli & 90 & Tuntas \\
\hline 13. & Shapira Yosi & 95 & Tuntas \\
\hline 14. & Ratu Kayla & 95 & Tuntas \\
\hline 15. & Taufik Hidayat & 70 & Tidak tuntas \\
\hline 16. & Bagas Febrian R. & 65 & Tidak tuntas \\
\hline 17. & Nur Fitriany & 95 & Tuntas \\
\hline
\end{tabular}

Copyright (C) 2020

Buana Matematika :

Jurnal Ilmiah Matematika dan Pendidikan Matematika 


\begin{tabular}{clcc}
\hline No & \multicolumn{1}{c}{ Nama Siswa } & Nilai Siklus II & Keterangan \\
\hline 18. & Putri Carla & 85 & Tuntas \\
\hline 19. & Laila Rachmadani & 70 & Tidak tuntas \\
\hline 20. & Humbela Putri Tael & 100 & Tuntas \\
\hline 21. & Adelia Nimalasari & 95 & Tuntas \\
\hline 22. & Adinda Trinita & 80 & Tuntas \\
\hline 23. & Bagus Febrian Shidiq & 70 & Tidak tuntas \\
\hline 24. & Ryansyah Rahmadani & 85 & Tuntas \\
\hline 25. & Dewi Fatmawati & 95 & Tuntas \\
\hline 26. & Melia Bimbi Ferdhianty & 70 & Tidak tuntas \\
\hline 27. & Nur Kholifah & 100 & Tuntas \\
\hline 28. & Priskila Tivena & 100 & Tuntas \\
\hline 29. & Fanny Octania & 95 & Tuntas \\
\hline 30. & Yulistia Blandina & 100 & Tuntas \\
\hline 31. & Muhammad Ryan & 100 & Tuntas \\
\hline 32. & Fania Tifara & 85 & Tuntas \\
\hline 33. & Shierly Alvany & 80 & Tuntas \\
\hline & Jumlah & & $\mathbf{2 9 2 5}$ \\
\hline & Rata-rata & $\mathbf{8 8 , 6 4}$ \\
\hline & Ketuntasan Klasikal & $\mathbf{8 1 , 8 2 \%}$ \\
\hline
\end{tabular}

Tabel 6 di atas menunjukkan analisis hasil tes secara individu maupun klasikal pada siklus II dengan menggunakan model pembelajaran kooperatif tipe STAD untuk mengetahui hasil belajar matematika siswa kelas X UPW SMK 17 Agustus 1945 pada pokok bahasan Operasi Bentuk Akar. Hasilnya menunjukkan bahwa, dari 33 jumlah siswa yang mengikuti tes, sebanyak 27 atau $81,82 \%$ siswa yang mendapat nilai $\geq$ nilai KKM sedangkan 6 atau 18,18\% siswa mendapat nilai < nilai KKM.

d) Refleksi (Reflection)

Berdasarkan data keaktifan belajar dan hasil belajar siswa di atas, maka dapat disimpulkan bahwa Penerapan model pembelajaran kooperatif tipe STAD pada siklus II sudah mencapai indikator keberhasilan baik secara individu maupun klasikal yang telah ditetapkan oleh peneliti yaitu untuk keaktifan siswa minimal $70 \%$ dan untuk hasil belajar secara individu minimal 75 (nilai KKM) dan secara klasikal minimal 75\% . Sehingga penelitian ini berhenti dan selesai pada siklus ke II

\section{Pembahasan}

\section{Keaktifan Siswa}

Berdasarkan analisis data hasil pengamatan yang ditunjukkan pada tabel 1.2 keaktifan siswa saat pembelajaran siklus I dan tabel 1.4 keaktifan siswa saat

\section{Buana Matematika :}

Jurnal Ilmiah Matematika dan Pendidikan Matematika 
pembelajaran siklus II dapat dilihat bahwa pada pengamatan siklus I, dari 29 siswa yang di amati, sebanyak 2 atau 6,06\% siswa mendapat kategori sangat baik, sebanyak 27 atau $81,82 \%$ siswa yang mendapat kategori baik, dan 4 atau $12,12 \%$ siswa tidak hadir saat pembelajaran Siklus I. Rata-rata persentase keaktifan siswa secara keseluruhan sebesar 67,64\% dengan kategori baik. Hal ini menjelaskan bahwa keaktifan siswa saat siklus I belum mencapai kriteria keberhasilan yang telah ditentukan yakni minimal $70 \%$ siswa yang hadir terlibat aktif. Pada pembelajaran siklus II terjadi peningkatan pada keaktifan siswa yakni sebanyak 16 atau $48,48 \%$ siswa mendapat kategori sangat baik dan sebanyak 17 atau 51,52\% siswa mendapat kategori baik, sedangkan ratarata persentase keaktifan siswa secara keseluruhan sebesar $75,76 \%$ dengan kategori sangat baik. Hal ini menjelaskan bahwa ada peningkatan keaktifan siswa dari siklus I ke siklus II serta sudah memenuhi kriteria keberhasilan tindakan. Dapat diambil kesimpulan bahwa penerapan model pembelajaran kooperatif tipe STAD (Student Teams Achievment Divisions) pada pokok bahasan operasi bentuk akar dapat meningkatkan keaktifan belajar siswa kelas X UPW SMK 17 Agustus 1945 Surabaya. Hasil temuan penelitian ini di dukung oleh hasil penelitian Nur dan Hudallah, (2015)mengatakan bahwa model pembelajaran kooperatif tipe STAD (Student Teams Achievement Division) dengan media kartu pintar dapat meningkatkan keaktifan siswa kelas VII F dalam proses pembelajaran TIK semester II di SMPN 1 Kandeman. Diperkuat juga dari hasil penelitian Putri dan Sutriyono, (2018) menunjukkan bahwa salah satu faktor yang dapat menentukan pencapaian hasil belajar adalah siswa untuk aktif dan bertanggung jawab dalam pembelajaran maka disarankan bagi siswa untuk terlibat aktif dalam proses pembelajaran, sehingga keaktifan belajar siswa berdampak pada peningkatan hasil belajar siswa di SMPN 3 Karanganyar.

\section{Pencapaian Hasil Belajar}

Perbandingan hasil belajar siswa saat pre-test, pada siklus I dan siklus II sebagai berikut: pada saat Pre-test, nilai rata-rata kelas yaitu sebesar 37,90 dan ketuntasan klasikal sebesar $24,24 \%$. Kemudian pada pelaksanaan siklus I nilai rata-rata kelas sebesar 68,79 dan ketuntasan klasikal sebesar 48,28\% dari jumlah siswa yang hadir. Ini menandakan bahwa hasil tes pada tindakan siklus I, belum mencapai kriteria keberhasilan yang ditetapkan yaitu minimal $75 \%$ siswa yang hadir mencapai nilai $\geq$ KKM serta ketuntasan klasikalnya minimal 75\%. Belum berhasilnya tindakan pada siklus I dikarenakan kegiatan belajarnya masih kurang serta aktivitas pada siklus I juga masih rendah. Pada siklus II, diperoleh nilai rata-rata kelas yaitu sebesar 88,64 dan ketuntasan Copyright $\odot 2020$

\section{Buana Matematika :}

Jurnal Ilmiah Matematika dan Pendidikan Matematika 
klasikal sebesar $81,82 \%$ dan pada saat test siklus II, jumlah siswa yang mendapatkan nilai $\geq$ KKM sebanyak 27 siswa atau 81,82\% dari semua siswa yang hadir. Karena hasil pada siklus II sudah mencapai kriteria keberhasilan maka penelitian ini berhenti pada siklus II. Hasil temuan dari penelitian ini di perkuat oleh hasil penelitian Arif, (2016) menyimpulkan bahwa ada pengaruh penerapan model pembelajaran kooperatif tipe STAD terhadap hasil belajar siswa pokok bahasan fungsi kelas VIII SMP Negeri 1 Sukodono tahun ajaran 2014/2015, hal ini dapat dilihat dari rata-rata nilai hasil belajar matematika siswa yang diajar dengan model pembelajaran kooperatif tipe STAD lebih tinggi yaitu 82,78 dari hasil belajar rata-rata peserta didik yang diajar dengan pembelajaran konvensional yaitu 71,62 pada materi Fungsi. Di dukung juga dengan hasil penelitian Putri dan Sutriyono, (2018) menyimpulkan bahwa penerapan model pembelajaran kooperatif tipe STAD dapat meningkatkan hasil belajar matematika pada siswa SMPN 3 Karanganyar, hal tersebut dapat dilihat dari pencapaian rat-rata hasil belajar pada siklus I sebesar 75.687 dan meningkat pada siklus II menjadi 81.156 dan sudah mencapai KKM yang sudah ditetapkan yaitu 75. Persentase ketuntasan klasikal pada siklus I 68.75\% (belum mencapai batas ketuntasan klasikal), namun pada siklus II persentase ketuntasan klasikalmya sebesar 93,75 \% (sudah mencapai batas ketuntasan klasikal). Dengan demikian, pada siklus II hasil belajar telah mencapai indikator keberhasilan sehingga pada PTK ini berhenti pada siklus II.

Berdasarkan hasil analisis data di atas, baik data keaktifan siswa maupun data hasil belajar siswa, menunjukkan bahwa penerapan model pembelajaran kooperatif tipe STAD dapat meningkatkan keaktifan dan hasil belajar siswa. Secara signifikan dapat dilihat bahwa pembelajaran dengan menggunakan model pembelajaran kooperatif tipe STAD lebih baik daripada pembelajaran Ceramah. Hasil temuan ini didukung penelitian (Eminingsih, 2013; Setyadi dan Supartini, 2014) yang menyimpulkan bahwa model pembelajaran kooperatif tipe Student Teams Achievement Divison (STAD) dapat meningkatkan keaktifan dan hasil belajar siswa. Diperkuat juga dengan hasil penelitian Nur dan Hudallah, (2015) mengatakan bahwa model pembelajaran kooperatif tipe STAD (Student Teams Achievement Division) dengan media kartu pintar dapat meningkatkan keaktifan belajar dan hasil belajar siswa kelas VII F dalam proses pembelajaran TIK semester II di SMP Negeri 1 Kandeman.

\section{Simpulan}

Copyright (C) 2020

Buana Matematika :

Jurnal Ilmiah Matematika dan Pendidikan Matematika 
Berdasarkan hasil analisis keaktifan siswa maupun hasil belajar siswa pada penelitian ini, dapat disimpulkan bahwa: 1) Penerapan Model Pembelajaran Kooperatif Tipe Student Teams Achievement Divison (STAD) dapat meningkatkan keaktifan belajar siswa pada materi operasi bentuk akar di kelas X UPW SMK 17 Agustus 1945 Surabaya; 2) Penerapan Model Pembelajaran Kooperatif Tipe Student Teams Achievement Divison (STAD) dapat meningkatkan hasil belajar siswa pada materi operasi bentuk akar di kelas X UPW SMK 17 Agustus 1945 Surabaya.

\section{Daftar Pustaka}

Ardillah, S. (2016). Pengaruh Model Pembelajaran STAD Dan NHT Terhadap Hasil Belajar Matematika Siswa Kelas X-1 Dan X-2 Akutansi. Buana Matematika : Jurnal Ilmiah Matematika Dan Pendidikan Matematika, 6(1:), 2532. https://doi.org/10.36456/buanamatematika.v6i1:.373

Arif, R. (2016). Pengaruh Penerapan Model Pembelajaran Kooperatif Tipe STAD Terhadap Hasil Belajar Siswa. Buana Matematika: Jurnal Ilmiah Matematika Dan Pendidikan Matematika, 6(1:), 11-18. https://doi.org/10.36456/buanamatematika.v6i1:.371

Arikunto. (2015). Penelitian Tindakan Kelas. Jakarta: PT. Bumi Aksara.

Desriyana, D. (2016). Penerapan Model Pembelajaran Kooperatif Tipe STAD

Penerapan Himpunan Di Kelas VII. Aksioma Journal Pendidikan Matematika, 5(3), 179-190.

Eminingsih. (2013). Peningkatan Hasil Belajar Matematika Melalui Pembelajaran Kooperatif Tipe STAD Pada Siswa Kelas VII E SMP Negeri 3 Batang. Lembaran Ilmu Kependidikan, 42(1), 29-35.

Kalim, N., \& Siti Andriani. (2013). Model Pembelajaran Kooperatif STAD

Dalam Meningkatkan Hasil Belajar Matematika (Cooperative Learning Model STAD To Improve Mathematics Result). Jurnal Pendidikan Matematika STKIP PGRI Sidoarjo, 1(1), 75-82.

Nur, A., \& Hudallah, N. (2015). Implementasi Model Pembelajaran Kooperatif Tipe STAD (Student Teams Achievement Division) Dengan Media Kartu Pintar Pada Mata Pelajaran Tik Kelas Vii Sebagai Upaya Untuk Meningkatkan Hasil Belajar Siswa SMPN 1 Kandeman-Batang. Edu Komputika Journal, 2(2),

https://doi.org/10.15294/edukomputika.v2i2.7849

Nurkhikmah. (2013). Keefektifan Penerapan Model Problem Based Learning

(Pbl) Terhadap Peningkatan Kualitas Pembelajaran Ipa. Journal of Elementary Education, 2(2), 19-24.

Putri, K. C., \& Sutriyono. (2018). P ENGARUH M ETODE P EMBELAJARAN Copyright (C) 2020

\section{Buana Matematika :}

Jurnal Ilmiah Matematika dan Pendidikan Matematika 
STAD TERHADAP H ASIL Mosharafa : Jurnal Pendidikan Matematika Persamaan Linear Dua Variable diperoleh Pair Share ), Team Assisted Individualization Mosharafa: Jurnal Pendidikan Matematika. Jurnal Pendidikan Matematika, 7(2), 295-306.

Rachmawati, R. S. ; I. (2018). Issn 2614-0357. Analisis Gabungan Strategi Memilih Notasi Yang Tepat Dan Membentuk Masalah Yang Setara Dalam Menentukan Sisa Pembagian, 3, 242-251.

Rusman. (2016). Model- Model Pembelajaran Mengembangkan Profesionalisme Guru. Bandung: PT. Raja Grafindo Persada.

Sari, S. R., \& Munoto. (2018). Pengembangan Perangkat Pembelajaran Menerapkan Model Pembelajaran Kooperatif Tipe TGT ( Teams Games Tournament ) Berbasis Permainan Ludo Untuk Meningkatkan Hasil Belajar Siswa Pada Mata Pelajaran Perekayasaan Sistem Antena Kelas XI SMK Negeri 3 Surabaya. Journal Pendidikan Teknik Elektro, 7(2), 215-223.

Setyadi, A. E., \& Supartini, S. (2014). Implementasi pendekatan science edutainment berbasis lesson study terhadap hasil belajar siswa biologi. JPBIO (Jurnal Pendidikan Biologi), 5(1), 12-19. https://doi.org/10.31932/jpbio.v5i1.550

Sudjana, N. (2016). Penilaian Hasil Proses Belajar Mengajar. Bandung: PT. Remaja Rosdakarya.

Vellayati, S. (2017). ANALISIS AKTIVITAS BELAJAR SISWA DAN AKTIVITAS PEMBELAJARAN GURU PADA MATA PELAJARAN KIMIA (Studi Kasus di SMA Negeri 8 Banda Aceh Tahun 2016/2017). Seminar Nasional Mipa III, 119-126.

Winkel. (1996). Psikologi Pengajaran. Gramedia.

Yudianto. (2014). Model Pembelajaran Teams Games Tournaments (TGT) untuk Meningkatkan Hasil Belajar. Ideas: Jurnal Pendidikan, Sosial Dan Budaya, 1(2), 36-43. https://doi.org/10.32884/ideas.v5i4.227

Copyright (C) 2020

Buana Matematika :

Jurnal Ilmiah Matematika dan Pendidikan Matematika 


\section{Riwayat Hidup Penulis}

Ardianik

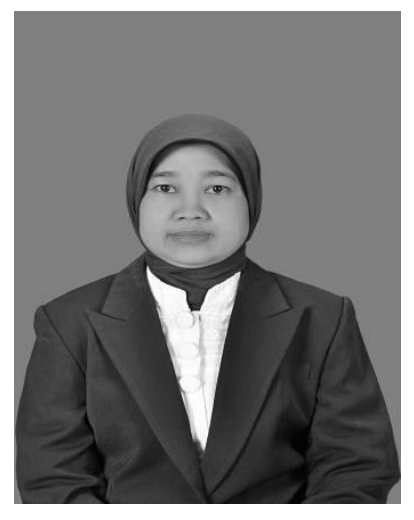

Sucipto

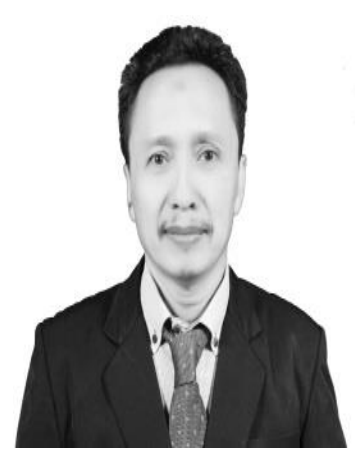

Lahir di Sidoarjo, 16 Mei 1965. Staf pengajar di Pendidikan Matematika FKIP Universitas Dr. Soetomo Surabaya. Studi S1 bidang Pendidikan Matematika FKIP Universitas Dr. Soetomo, lulus tahun 1989; S2 bidang Biostatistik Universitas Airlangga Surabaya, lulus tahun 2002; dan S2 bidang Pendidikan Matematika Universitas Muhammadiyah Malang, lulus tahun 2017. Aktif menulis artikel di berbagai jurnal nasional maupun internasional, dan pemakalah di berbagai seminar nasional maupun internasional di bidang matematika.

Lahir di Magetan, 10 Pebruari 1968. Staf pengajar di FKIP Universitas Dr. Soetomo. Studi S1 bidang Teknologi Pendidikan IKIP Negeri Surabaya, lulus tahun 1991; S2 bidang Ilmu Komunikasi Universitas Dr. Soetomo, Surabaya, lulus tahun 2004; dan S3 bidang Teknologi Pendidikan Unesa, Surabaya, lulus tahun 2019. Aktif menulis artikel di berbagai jurnal dan narasumber dalam seminar bidang Teknologi Pendidikan. 